\title{
İşletmelerde İç Denetim Faaliyetlerinde İç Denetim Yazılımının Kullanımının Avantajları ve
} Dezavantajları

\section{Advantages and Disadvantages of Using Internal Audit Software in Internal Audit Activities in Businesses}

\author{
Ali Durdu' ${ }^{1}$, Gürbüz Aydın² (1)
}

${ }^{1}$ (Dr. Öğr. Üyesi), Ankara Sosyal Bilimler Üniversitesi, Siyasal Bilgiler Fakültesi, İşletme Bölümü, Ankara, Türkiye

${ }^{2}$ (Yüksek Lisans Öğrencisi), Ankara Sosyal Bilimler Üniversites, i Denetim ve Risk Yönetimi Programı, Ankara, Türkiye

ORCID: A.D. 0000-0002-5347-4491; G.A. 0000-0002-2049-3928

Corresponding author:

Ali DURDU

Ankara Sosyal Bilimler Üniversitesi, Siyasal Bilgiler Fakültesi, İșletme Bölümü, Ankara, Türkiye

E-mail address: ali.durdu@asbu.edu.tr

Submitted: 07.04 .2021

Revision Requested: 20.06 .2021

Last Revision Received: 08.07.2021

Accepted: 25.07.2021

Published Online: 14.10 .2021

Citation: Durdu, A. ve Aydin G. (2021). İşletmelerde iç denetim faaliyetlerinde iç denetim yazılımının kullanımının avantajları ve dezavantajlar1. Acta Infologica, 5(2), 475-489. https://doi.org/10.26650/acin. 927446
ÖZ

Bu çalışmada, iş̧letmelerde iç denetim süreçlerinde bir iç denetim yazılımı kullanımının sağladığı faydalar incelenmiştir. Çalışma ile yazılım kullanımı olmadığı durumlarda iç denetim süreçlerinin ve faaliyetlerinin nasıl sürdürüldüğü, olası aksaklıklar ve iyileştirilmesi gereken adımlara yer verildikten sonra yazılım kullanımı sonrası iç denetim faaliyetleri de irdelenmiştir. Konunun daha önce ülkemizde bu detayda incelenmediği, yapılan çalışma ile iç denetim yazılımı kullanmanın iç denetim faaliyetlerine sağladığı etkilerin neler olduğunun gözler önüne serilmesi anlamında literatüre katkı sağlayacağı düşünülmektedir. Bu durumda yazılım kullanımı ile ilgili hususlar öncelikle yazılımın satın alma yoluyla tedarik edilmesi ve yazılımın şirket iç kaynaklarıyla geliştirilmesi sonuçlarına göre açıklanmaya çalışılmıştır. Bununla birlikte dışarıdan satın alma yoluyla iç denetim yazılımının tedarik edilmesi durumunda maliyet, kullanım kolaylığı gibi hususlar yazılımın şirket kaynakları tarafından geliştirilmesi durumundaki olası maliyetleri ve avantajları kapsamında da karşılaştırılmıştır. Çalışma kapsamında iç denetim yazılımı kullanmayan iç denetim birimlerinin denetçileri, yazılım kullanan ancak dışarıdan satın alınan iç denetim birimlerin denetçileri ve en son olarak da şirket içi kaynaklarla kendi geliştirdikleri iç denetim yazılımını kullanan denetçilerin görüşleri ve açıklamaları dikkate alınarak bu araştırma hazır hale getirilmiştir.

Anahtar kelimeler: İç denetim, Yazılım, Fayda, Maaliyet, Avantaj

\section{ABSTRACT}

In this article, the advantages of using internal audit software in the internal audit processes of the companies are analyzed. With this article, the manner in which internal audit processes and operations are executed, potential problems, and steps that should be improved are provided in cases where an internal audit software is not used, then, internal audit operations are examined after the usage of the software. It is thought that the contribution of this study to the literature is mainly originated from the fact that there is no other study in which the subject in question is deeply examined in our country and this article mentions the impacts of the usage of internal audit software on the internal audit operations. In this context, the issues regarding the usage of the software are explained, firstly, by the procurement of the software via purchasing, and then by developing the software by using the company's internal resources. Moreover, considerations such as cost, ease of usage, and where the internal audit software is procured via external purchasing are also compared with the potential costs and advantages where the software is developed by the company's resources. The article was finalized by taking into consideration the opinions and the explanations of the auditors of the internal audit departments who do not use any internal audit software, auditors who use internal audit software which is procured via external purchasing, and lastly, the auditors who use in-company developed audit software.

Keywords: Internal audit, Software, Business, Benefit, Cost 


\section{GİRIŞ}

Günümüzde gelişen teknoloji ile bilgi sistemleri artık tüm iş alanlarında kullanılır hale gelmektedir. Teknolojinin bu denli gelişmesi işletmeleri bilgi sistemleri kullanmaya zorlamakta ve rekabeti arttırmaktadır. Küreselleşen dünyada bilgiye ulaşmak son derece kolayken bu teknolojinin iş hayatında kullanımı hem işleri kolaylaştırırken hem de iş verimliliğini arttırmaktadır. Literatürde bilgi sistemlerinin küreselleşmeye ve işletmelere etkisi üzerinde pek çok çalışma bulunmaktadır. Akolaş (Akolaş, 2004) çalışmasında bilgi sistemlerinin küreselleşme olgusu üzerindeki etkilerini incelemiştir. Bilgi sistemleri ve sağladığı faydalar konusunu inceleyen yönetim bilişim sistemleri, karar verme ve bir organizasyondaki bilgilerin koordinasyonu, kontrolü, analizi ve görselleştirilmesi için kullanılan bir bilgi sistemidir (Gökçen, 2011).

Yönetim bilişim sistemleri, bilgi teknolojileriyle işlemleri ve süreçleri kolaylaştıratak işletmelerin gelişmesi ve verimliliğine katkı sağlamaktadır (Çelik ve Akgemci, 2010). Şahin çalışmasında (Şahin, 2014) bilişim sistemlerinin işletme performansına etkilerini incelemiş̧tir. Çalışmada bilişim sistemlerinin işletmeye sağladığı faydaları; verimlilikte artış sağlamak, kaliteli hizmet sunmak, maliyetleri düşürmek, yeni ürünler geliştirmek ve işletmenin rekabet gücünü artırmak olarak sıralamıştır. Durdu ve İpek çalışmalarında (Durdu ve İpek, 2020) bilgi yönetiminin işletmelere yenilik ve rekabet üstünlüğü sağlaması üzerine çalışmışlardır. Buna göre çalışmada bilgi yönetiminin işletmelerde rekabet avantajı sağladığı ve işletmelerin pazar değerini artırdığı vurgulanmıştır. Emhan (Emhan, 2007) bilişim sistemleri kullanımın işletmelerin karar verme sürecindeki etkilerini incelemiş ve bilgi sistemlerinin işletmelerde yöneticilerin karar alma süreçlerinde doğru bilgiyi ve ham verilerden süzülen rapor verilerini kullanarak yardımcı olduğu belirtilmektedir. Ayrıca örgütlerin güvenilir ve rafine bilgileri elde etmek için yönetim bilişim sistemlerin kullandıkları vurgulanmıştır.

Elibol (Elibol, 2005) bilişim teknolojilerinin işletmelerin organizasyon yapısı üzerindeki etkilerini incelemiştir. Elibol'un çalışmasına göre bilişim teknolojilerinin işletmelerin bütün faaliyetlerinde yoğun bir şekilde kullanılmaya başlamasıyla birlikte işletmeler, teknolojiyi etkin bir şekilde kullanabilmek için yeniden yapılanmak durumunda kaldıkları belirtilmiştir.

Damar ve arkadaşları (Damar ve ark., 2019) çalışmalarında yazılım kullanmanın tüm işletmeler için günümüz dünyasında bir zorunluluk olduğunu belirtmişler ve eğer işletmeler ticari hayatta yaşamlarını sürdürmek istiyorlarsa bunun faaliyetlerine uygun yazılımlar seçmelerine bağlı olduğunun altını çizmişlerdir. İlaveten yazılımın seçiminin doğru yapılamamasının da işletmeler açısından bir takım olumsuz sonuçlar doğurabileceği üzerinde durmuşlar ve bunlar içinde gerek mali gerek müşteri memnuniyeti ve gerekse tedarik uygulamaları gibi daha birçok açıdan farklı ek maliyetlere yol açabileceğine dikkat çekmişlerdir.

Öte yandan iç denetimin gerek üst yönetime ve gerekse bütüncül olarak bakıldığında bağlı olduğu kuruma karşı görev ve yükümlülükleri dikkate alındığında etkin ve verimli çalışması için iç denetim yazılımlarının kullanımı artık bir iyi uygulama olmaktan öte genel olarak kullanımı tüm dünyada yayılım gösteren bir gereklilik haline gelmektedir.

İç denetim faaliyetlerinin gerek planlama, saha çalışmaları, raporlama, bulgu takip gibi süreçlerinin yürütülmesinde ve gerekse iç denetim faaliyetinin/biriminin performansının tarafsız ve adil gerçekleştirilebilmesinde iç denetim yazılımları eğer doğru kullanılırsa önemli kolaylıklar ve tasarruf sağlama noktasında faydalı sonuçlar da üretmektedir. Bu bağlamda iç denetim yazılımının iç denetim süreçlerine sağladığı katkılar üzerine bir çalışma yapılmıştır.

Manuel olarak yürütülen iç denetim süreçlerinden iç denetim yazılımı kullanılarak yürütülen iç denetim süreçlerine geçişe dair karşılaştırmalı spesifik bir çalışmaya ulaşılmamakla birlikte genel hatlarıyla iç denetim yazılımları hakkında literatürde bir takım çalışmalar yapıldığı görülmüştür.

\section{2. İÇ DENETIMM}

Türk Dil Kurumu sözlüğünde yer aldığı şekliyle denetim veya denetleme, bir görevin yolunda yürütülüp yürütülmediğini anlamak için yapılan araştırma, denetim, bakı, teftiş, murakabe, kontrol anlamına gelmektedir (Türk Dil Kurumu Sözlükleri, 2021, Nisan 25).

IIA (Institute of Internal Auditors - İç Denetçiler Enstitüsü) tarafından tanımlandığı şekliyle ise iç denetim "Bir kurumun faaliyetlerini geliştirmek ve onlara değer katmak amacını güden bağımsız ve objektif bir güvence ve danışmanlık faaliyetidir. 
İç denetim, kurumun risk yönetim, kontrol ve yönetişim süreçlerinin etkililiğini değerlendirmek ve geliştirmek amacına yönelik sistemli ve disiplinli bir yaklaşım getirerek kurumun amaçlarına ulaşmasına yardımcı olur" (Türkiye İç Denetim Enstitüsü (TIDE), 2021, Nisan 25).

Küreselleşme ve dünyanın sürekli değişimi dikkate aşındığında iç denetim fonksiyonunun ve faaliyetlerinin ne kadar önemli bir konuma geldiği artık daha iyi anlaşılmaktadır. Şöyle ki, işletmeler, süreçlerinin ve kontrollerinin daha iyi tasarlanıp etkin çalışması ve risklerinin daha iyi yönetilebilmesi böylelikle de kayıpların önlenerek işletme hedeflerine ulaşılabilmesinde iç denetimin ne denli kritik bir rol üstlendiğini daha iyi anlamaktadırlar (İç Denetim Portali, 2021, Nisan 25).

Öte yandan, Gökçen ve Yelken (Gökçen \& Yelken, 2019) çalışmalarında işletmelerin operasyonlarının gittikçe daha karmaşık bir hal almasından ve ayrıca sahip oldukları varlıkları koruma ihtiyaçları olmasından ötürü, olası hata ve hileleri önleyerek finansal bilgilerin doğruluğunu sağlamak amacıyla iç denetim kurulması gereksinimini arttırdığına değinmişlerdir.

Yukarıdaki tanımları bir araya getirdiğimizde iç denetimin işletmelerin etkin olarak faaliyetlerini sürdürebilmesi ve işletme hedeflerine ulaşılabilmesi açısından kritik önemi bulunduğu sonucuna ulaşılabilir.

Gencer (Gencer, 2014) ise araştırmasında, iç kontrol sisteminin etkin olarak işleyebilmesinde iç denetimin etkisine ve önemine değinmiş, iç denetimin, aslında iç kontrol yapısının tasarlandığı şekilde faaliyet gösterip göstermediğini inceleyen ve bu inceleme sonucunda karar alıcılara raporlama yapan bir fonksiyon olduğundan, olası olumsuzluklarda ihtiyaç duyulan önlemlerin ve aksiyonların alınmasında önemli bir rolü olduğunu ifade etmiştir.

Kurnaz ve Çetinoğlu (Kunaz \& Çetinoğlu, 2010) iç denetimin amacının işletmelerin yönetim kademesinde yer alan kişiler ile karar alıcılarınınım sorumluluklarını yerine getirirken çalışmaları ile onlara yardımcı olmak olduğunu belirtmektedirler. Ayrıca, Ceyhan (Ceyhan, 2010) ise iç denetimin temel amacını dört maddede toplamış ve bunların mevcut kontrollerin yeterli ve etkin olup olmadığının incelenmesi, varlıkların zararlara karşı korunup korunmadığının denetlenmesi, devam eden işletme operasyonlarının düzenlemelerle uyumlu olup olmadığınınım araştırılması, son olarak da mali tabloların doğruluk ve güvenilirliğinin sorgulanması olarak tanımlamıştır.

Dolayısıyla iç denetim, işletme hedeflerine ulaşmada bir problem olup olmadığı, mali ve manevi olarak bir zarar tehdidinin bulunup bulunmadığı, mevzuat ve iç prosedür hükümlerine uyum konusunda sıkıntılar olup olmayacağı konularını bir araya getirip yönetime mevcut durum ve gelecek hakkında bir ışık tutmayı hedeflemektedir. Tabi bu görevini de layıkıyla yerine getirmesi ancak planlı ve disiplinli bir çalışma sayesinde olabilir. Güvence açısından değerlendirildiğinde ise iç denetim, bir işletmenin hedeflerine ulaşmasına yardımcı olmak üzere mevcut süreçler ve ilgili kontrollere ilişkin güvence sağlar (Türkiye İç Denetim Enstitüsü (TIDE), 2021, Nisan 25).

Ancak çalışmanın konusu bu unsurlar arasındaki ilişki ve önemi olmadığından daha detaya açıklamaya gerek olmadığı düşünülmektedir.

Öte taraftan, Sağlar ve Tuan (Sağlar \& Tuan, 2009) çalışmalarında iç denetimin temel görevleri aşağıdaki şekilde sıralamışlardır:

> İç kontrol sistemi hakkında güvence vermek,

Kurum için uygun politika ve prosedürlerin tespitini güvence altına almak,

> Kurumun süreçlerini ve kontrollerini takip etmek,

Yönetim kurulunun kendisine bağlı denetim komitesi ile koordineli raporlama sürecini yürütmek,

Mevcut iç kontroller hakkında uygunluk ve etkinlik bakımında görüşlerini denetim komitesine iletmektir.

\section{3. İÇ DENETIM YAZILIMLARI}

Türk Dil Kurumu sözlüğünde yer aldığı şekliyle yazılım, donanımın istenildiği şekilde işlemesini sağlayan her türlü program, programlama dilleri ve belgelemeleri olarak tanımlanmaktadır (Türk Dil Kurumu Sözlükleri, 2021, Nisan 25). Daha farklı bir anlatım ile ifade edersek; gündelik hayatta veya iş hayatında kullanıcılarının işlerini daha hızlı yapmasına olanak sağlayan 
ve iletişimi kolaylaştıran dolayısıyla zamandan tasarruf sağlayan, daha verimli çalışmaya imkân veren ve özel veya işle ilgili görevler için kullanılan programlardır (Yazılımnet Bilişim Teknolojileri, 2021, Nisan 25).

Burada önemli olan yazılımın, süreden tasarruf sağlarken aynı zamanda iletişimi daha hızlı ve kolay hale getirmesinin yanında verimliliği de arttıran ve bu yönleriyle kullanıcıların işlerini kolaylaştıran bir özelliği bulunmaktadır.

Yazılımların bulunmadığı günlük veya iş hayatı neredeyse yoktur denilebilir. Şöyle ki akıllı telefonlar, televizyonlar, beyaz eşya makineler, internet, gibi cihazlar üzerinde işlem yaparken zaten bu yazılımlar sayesinde istenilen sonuçlara ulaşılmakta ve bu yazılımlar hayatımızın her anına bir nevi temas etmektedir (Branding Türkiye, 2021, Nisan 25).

İş hayatı göz önüne alındığında kamu ve özel sektörde kurumlar operasyonlarını kayıt altına alabilmek ve etkin olarak operasyonlarını yönetebilmek adına yazılımları kullanmaktadırlar (Damar ve ark., 2019).

Yazılım türleri ise genel olarak kabul gördüğü üzere ikiye ayrılmaktadır: sistem yazılımları ve uygulama yazılımları. Bilgisayar kullanıcılarının bazı belli başlı işlemleri yapabilmelerine olanak sağlayan yazılımlara uygulama yazılımları adı verilmektedir. Uygulama yazılımları farklı kaynaklarda farklı sayıda sınıflandırılmaktadır. Ancak genel kabul göre hali ile yazılımları iki kategoride sınıflandırmak mümkündür.

1. Genel Amaçlı Uygulama Yazılımları: Ofis uygulamaları (Microsoft Office, Excel, PowerPoint) gibi yazılımlardır.

2. Özel Amaçlı Uygulama Yazılımları: Birtakım özel işlemlerin gerçekleştirilebilmesine olanak sağlayan ve belirli koşullar kapsamında kullanılabilen yazılımlardır.

Diğer bir sınıflama da Paket Uygulama Yazılımları, Müşteriye Yönelik Yazılımlar (Tailor-made software) ve Genel Amaçlı Paketler şeklinde yapılabilir (Babagil, 2021).

Özel yazılım olarak da adlandırılabilen Müşteriye Yönelik Yazılımlar (Tailor-made software) genel olarak rutin veya rutin olmayan işlerin yapılış süresini kısaltan dolayısıyla hızı ve verimliliği artıran yazılımlar olarak ifade edilebilir. Çoğu kurumsal işletmelerde kullanılmakta olan muhasebe, İK, satın alma birimlerinde kullanılan uygulamaları bunlara örnek verilebilir. Bu tür yazılımlar web veya mobil uygulama üzerinden erişilip kullanılabilmektedir (Yazılımnet Bilişim Teknolojileri, 2021, Nisan 25).

Yazılımlardan bahsettikten sonra neden yazılım kullanımı iç denetim fonksiyonu açısından önem arz etmektedir sorusu akıllara gelmektedir. Bu bağlamda günümüzde şirketlerin neredeyse tamamı gerek muhasebe işlemlerini ve gerekse muhasebeye girdi oluşturan diğer işlemlerini bilgisayar ve ilgili programlar dâhilinde gerçekleştirmektedir.

Ayrıca özellikleri gereği iç denetim yazılımlarının kurumun diğer tüm süreçlerinden ve sistemlerinden bilgi aldığı ve bunlarla etkileşim hali içinde olduğu dikkate alınırsa birer yönetim bilişim sistemi (YBS) özelliğini de taşıdığı söylenebilir. Şöyle ki; Damar ve Coşkun (Damar \& Coşkun, 2017) çalışmalarında YBS’nin bir işletmenin tüm yönetim, bilişim ve bilgi teknoloji süreçleri ile ilgilendiğini, bu iş süreçleri ile sürekli etkileşim halinde olduğunu ve onlarla bütünleşik düşünülmesi gerektiğini vurgulamaktadir.

Bilgen (Bilgen, 2019) yönetim bilgi veya bilişim sistemleri denilince de akla bilgi ve yönetim kavramlarının geldiğine dikkati çekerek işletmelerde verimlilik, etkinlik ve performans iyileştirmesi gibi unsurların gittikçe daha önemli hale geldiğini ve bu durumun YBS ihtiyacını da arttırdığını belirtmiştir. Ayrıca YBS'nin öneminin kullanıcılara hızlı ve kolay bilgi sağlamasıyla ilgili olduğunu vurgulamıştır.

Dolayısıyla denetlenen birimlerin işlemlerini belli bilgisayar programları ve yazılımlar üzerinden takip ettiği dikkate alındığından iç denetimin de günü yakalamak ve işlemlerini aşağıdaki hususları - bunlarla sınırlı olmamak kaydıyla - dikkate alarak bir iç denetim yazılımı ile takip etmesini beklemek doğru olacaktır:

Gerek şirketten ve gerekse diğer lokasyonlardan (VPN) ile bağlanabilmeye imkân sağlayan erişim kolaylığg1,

> Güvenilir çalışma ortamı, 
Aynı andan birden fazla kişinin kullanabilmesi,

Denetim aşamaları hakkında yönlendiren,

$>$ Onay mekanizmasının dijital olarak ve hızlı sağlandığı,

Gözden geçirmelerin sistem üzerinden daha güvenilir ve hızlı olduğu,

> Yapılan tüm işlemlere dair (denetim planlama, saha çalışması, raporlama, bulgu takibi gibi) arşiv olarak kullanılabilmesi,

Tüm yapılan işlemlere (yükleme, değiştirme, onaylama, silme gibi) dair izleme (log) kayıtlarının bulunabildiği,

Kullanıc1 dostu bir ara yüzün bulunduğu,

Mümkünse diğer şirket sistemleri ile entegre olup çevrimiçi veya çevrimdışı veri çekilebilen bir sistem olması,

Kaliteli ve isteğe bağlı raporlama imkânları olmasından ötürü etkin bir YBS olarak faydalanılabilmesi,

En önemlisi raporlama modülünün bulunması ve etkili kullanımına olanak vermesi böylece gerek karar destek aracı olması ve gerekse performans takiplerinde kolayca kullanılabilmesi gibi.

Uygulamada iç denetim yazılımları, paket uygulama yazılımları veya müşteriye yönelik yazılımlar olarak ticari piyasada yer almaktadır. Paket yazılımlar genel olarak tüm şirketlerin ortak ihtiyaçlarına göre hazırlanmış, sektör, lokasyon, ülke, kullanıcı tecrübesi, müşteri bazında özel ihtiyaçlar öncelik olarak yer alamamış yazılımlardır. Ancak bunlar çok sayıda ülke ve sektöre hitap ettiği ve belli bir markası olduğundan piyasada ön sırada yer almaktadır. Maliyet açısından düşünüldüğünde ise eğer alım bedeli, periyodik bakımlar, kullanıcı lisansları gibi kalemler dikkate alındığında şirketler açısında önemli yük kalemi olabilmektedir. Ayrıca paket yazılımlardan yola çıkılarak bu yazılım üzerinden müşterinin özel gereksinimlerine dair birtakım geliştirme veya uyarlamalar talep edildiğinde maliyet tutarları daha da artmaktadır.

Günümüzde paket yazlımlar genellikle sadece iç denetime yönelik olarak değil iç kontrol, iç denetim, risk yönetimi, uyum, BT yönetişimi gibi modüllerin bulunduğu birden çok hususa hitap ve hizmet edecek şekilde tasarlanıp piyasada tek bir ürün (GRC-Governance, Risk and Compliance) olarak satılmaktadır. Bu paket yazılımlardan maksimum fayda sağlanmak isteniyorsa bu modüllerin tamamının kullanılması, şirkette kullanılan diğer sistemlerle entegre olması, şirket tarafından benimsenmesi, kullanıcı dostu ara yüzlerinin bulunması gibi etkenlerin göz önünde bulundurulması uygun olacaktır. Zira bu yazılımlar için ödenen bedeller (alım bedeli, periyodik bakım giderleri, kullanıcı lisansları gibi) sadece bir modül için değil tamamı için ödenmektedir.

İç denetim birimleri tarafından gerek yurt içinde gerekse yurtdışında kullanılan denetim yazılımları bulunmaktadır. Ülkemizde kurumsal ölçekteki işletmelerde bu tip yazılımların daha çok kullanıldığı söylenebilir. Ancak piyasada bu tip yazılımların sayısı oldukça az ve tedarik maliyeti de oldukça yüksek olabilmektedir (Kaya, 2021).

İç denetim yazılımlarında diğer bir alternatif ise eğer Müşteriye Yönelik Yazılımlar (Tailor-made software) olarak gösterilebilir. Şirketinizde uygulama geliştirme alanında uzmanlaşmış bir ekip bulunmuyorsa ve talebi dışarıya yaptırmanız söz konusu oluyorsa bazen paket programlardan çok daha pahalıya mal olma tehlikesi olabilir. Ancak diğer taraftan uygulama geliştirme ekipleriyle beraber bu yazılım geliştirme projesinde denetçilerin de görev almasıyla birlikte tam olarak iç denetim biriminin beklentilerini azami oranda karşılayabilecek yazılım elde etme potansiyeli oldukça yüksek olmaktadır.

Şirketinizde uygulama geliştirme alanında uzmanlaşmış bir birim varsa in-House denilen yöntemle diğer bir ifadeyle tamamen şirketin iç kaynaklarıyla denetim yazılımı üretme imkânı bulunuyorsa bu sefer ne satın alma maliyeti ne periyodik bakım gideri ne de kullanıcı lisansı ödeme ihtimali olmayacaktır. Bu da şirket için tasarruf anlamına gelmektedir. Bu arada her ne kadar bu tür in-House bir yazılımın alım bedeli gibi maliyetleri olmasa da uygulama geliştirme evresinde bu yazılım projesinde çalışan gerek yazılım geliştirme uzmanlarının gerekse denetçilerin bu iş için harcadıkları zaman maliyet tutarını oluşturacaktır. Bunlar dışında ayrıca bazı gider kalemleri de oluşabilecektir ancak dışarıdan alınan bir paket program veya yine dışarıya özel yaptırılan bir yazılım kadar maliyet oluşturmayacaktır. 


\section{4. İÇ DENETIM SAFHALARI}

Birçok kaynakta yer verildiği ve tanımlandığı üzere iç denetim süreci denetim planının hazırlanıp yetkili makam tarafından onaylanması ile başlamalıdır. Onay kritik önemdedir ve onaylı olmadıktan sonra geçerliliği de bulunmayacaktır. Sonrasında onayı denetim planı yıl içinde yapılacak denetim çalışmaları, projeler, danışmanlık konuları ve özel amaçlı denetim faaliyetleri için hem bir rehber olacak hem de dayanak oluşturacaktır (Ekşi, 2021).

Günşen (Günşen, 2016) çalışmasında kamu tarafında yürütülen iç denetim faaliyetlerine ilişkin süreçlerin planlama, denetimin yürütülmesi, raporlama ve sonuçların izlenmesi olmak üzere dört ana kalemden oluştuğunu belirtmiştir. Öte yandan özel sektördeki uygulamaları dikkate alındığında iç denetim bire bir kamudaki uygulama ile örtüşmese de genellikle aynı süreç ve aşamalardan geçtiği görülmektedir.

Yukarıda bahsi geçen süreçler uygulamada iç denetçiler tarafından her bir denetim esnasında gerçekleştirilmesi gerekmektedir. Bulgulara dair süreç sahiplerinden alınan aksiyon planları ve tahmini tamamlanma tarihlerine ilişkin bulgu (aksiyon planı) çalışmalarının da sonuçların izlenmesi aşaması içinde düşünülmesi yerinde olacaktır.

Ayrıca şu hususu belirtmekte fayda vardır ki bir iç denetim çalışması sürecinde yapılan testler, çalışmalar, bunlara ilişkin sonuçların ilgili kontrol (gözden geçirme) ve onay mekanizmasında geçirilmesi, gerekiyorsa revize edilmesi sonrasında da gerektiğinde ibraz edilebilecek şekilde muhafaza edilmesi beklenmektedir.

\section{5. İÇ DENETIMM YAZILIMI KULLANIMI - MANUEL VE OTOMATIZZE SÜREÇLER}

\section{1. İç denetim yazılımı kullanılmaması durumunda}

İç denetim faaliyetleri ve ilgili süreçleri dikkate alınarak yeni kurulmuş modern bir iç denetim birimini ele alırsak şu hususlar karşımıza çıkmaktadır; yeni prosedürlerin hazırlanması, yeni bir iş yapış şekli, iç denetim esaslarının oluşturulması, iç denetim rehberi hazırlanması, çalışacak profesyonellerin işe alımı ve bu yeni personelin farklı sektör ve tecrübelerden bir araya geldiği mozaik yapıya istinaden herkese hitap edecek ve eğitecek eğitimlerin aldırılması gibi önemli adımların uygulamaya başlaması gibi.

Bu hususlar dikkate alınarak benzer süreçleri tecrübe etmiş denetçilerle yapılan görüşmeler neticesinde, iç denetim yazılımı kullanımı olmadan manuel olarak süreçlerin ve onay mekanizmalarının işletildiği iç denetim birimlerinde iç denetim safhalarına ve uygulamalarına dair daha detay bilgiye özet olarak aşağıda yer verilmektedir.

\subsubsection{Planlama}

Denetimin planlama adımında denetim evreninin ve denetim alanlarının belirlenmesi, risklerin ortaya konulması ve risklerin değerlendirilmesi, denetim alanlarının önceliklendirilmesi, denetim kaynaklarının dağıtımı, denetim çalışma programının hazırlanması ve onaylanması, denetlenecek birimlere bildirimlerin yapılması gibi adımlar yer almakta olup, genel olarak tüm bu adımlar manuel süreçlere bağlıdır. Manuel olarak işlemlerin sürdürüldüğü bu iç denetim birimlerinde, aynı şekilde bu aşamaların olması gerektiği gibi tamamlanıp tamamlanmadığına dair gözden geçirmeler ve onaylar da manuel ve çoğunlukla sözlü olarak ilerletilen adımlardan oluşmaktaydı. Dolayısıyla, bazı denetçiler tarafından bu aşamadaki adımların tamamlanması gereği bilinmemekteydi.

Bu noktada denetçileri yönlendirecek manuel süreçlerden ziyade her gün sürekli kullanılan/kullanılması gereken yazılım olması gereken iç denetim aşamaları, gerek gözden geçirme ve onaylar ve gerekse yönlendirmeler konusunda oldukça yol gösterici olabilecekti.

\subsubsection{Denetimin yürütülmesi}

Manuel olarak işlemlerin sürdürüldüğü ve gerekli hassasiyetin gösterilmediği iç denetim birimlerinde denetimin yürütülmesi aşamasında yapılan çalışmalar, denetçinin inisiyatifinde herhangi bir yazılı dokümantasyon ve amir onayı gerektirmeden yapılan çalışmalardı. Dolayısıyla, konuya hassasiyeti olmayan denetçiler bu aşamadaki adımları yerine getirmesi gerektiğini dahi bilememekteydi. Ancak buradaki kritik husus bunların yapılması gereğine dair denetçilere bu konuda yeteri bilgilendirme, yönlendirme ve eğitimin de verilememiş olması demek yanlış olmazdı. 
Bu noktada denetçileri yönlendirecek manuel süreçlerden ziyade her gün sürekli kullanılan/kullanılması gereken yazılım olması gereken iç denetim aşamaları, gerek gözden geçirme ve onaylar ve gerekse yönlendirmeler konusunda oldukça yol gösterici olabilir.

İç denetim yazılımı kullanılmaksızın iç denetim süreçleri içindeki açılış toplantısı yapılması, risk değerlemesi yapılması, denetim testlerinin yapılması gibi denetimin yürütülmesi esnasındaki diğer adımlarla ilgili olarak genel itibariyle tüm süreç adımlarının manuel olarak yürütülmesi, yapılan çalışmalarda ve dokümantasyonda yeknesaklığın bulunmaması, arşivlemenin sadece denetçi bilgisayarlarında bulunması, denetim esnasında yapılan risk değerlendirmesi ve sonuçlarından başka çalışmalarda faydalanılamaması, bazı adımların yapılmaması/atlanması gibi birçok hususta olumsuzluklarla karşılaşılabilir. Bu durum da çalışmaların verimsiz ve etkin olmadan yürütülmesini sonucunu doğurabilir.

\subsubsection{Raporlama}

Çalı̧̧maya görüşleri ve açıklamalarıyla katılan meslek profesyonellerinin açıklamaları doğrultusunda bu iç denetim süreci aşaması için belki de denetim yönetimi ve denetçiler tarafından en çok hassasiyet gösterilen denetim aşaması demek yanlış olmaz. Şöyle ki; bu süreç nihai denetim raporunun gerek denetim yönetimi tarafından gözden geçirilmesi ve onaylanması, gerekse sonrasında denetlenen birimlerle mutabakatı ve sonrasında şirket üst yönetimi ve sonrasında Denetim Komitesi ile paylaşılması adımlarını içerdiğinden oldukça önem arz etmekteydi. Arşivleme açısından da taslak raporlar olmasa da nihai raporların arşivlemesi manuel olarak yazılı çıktılar şeklinde fiziki arşivde saklanmaktaydı. Mutabakata konu taslak rapor versiyonları ise denetçilerin bilgisayarlarında veya e-mail arşivlerinde bulunabilmekteydi.

\subsubsection{Denetim sonuçlarının izlenmesi}

Adiloğlu (Adiloğlu, 2010) çalışmasında iç denetçiler tarafından yapılan denetim çalışmaları sonucunda elde edilen bulgulara dair aksiyonların iç denetçiler tarafından takip edilmesinin önemli olduğuna dikkati çekmektedir. Dolayısıyla, süreç sahipleri tarafından verilen aksiyon planlarının zamanında uygulanılıp uygulanmadığının izlenmesi ve ilgili sorumlu taraflara zamanında ve doğru bilgilendirme yapmanın kritik olduğu ifade edilmektedir.

Yazılım kullanılmaması durumunda karşıllaşılan hususlarla ilgili çalışmaya katılan katılımcılardan alınan bilgilere göre, denetim raporlaması tamamlandıktan sonra bulgulara dair gerekli aksiyonların belirlenen vadelerde alınıp alınmadığı, alınmadığıysa gerekçeleri, olası yeni aksiyon planlarının alınması gibi işlemlerin takibi denetçilerin kendi münferit tuttukları Word veya Excel dokümanlarında takip edilmekteydi. Dolayısıyla ada hangi denetimin hangi bulgusunun kapatıldığına dair yönetime anlık bir raporlama yapılması veya karar vericilere destek olacak bir raporlama mekanizması bulunmamaktaydı. Diğer aşamalarda olduğu gibi bunlar da yine gerekli onay mekanizmaları bulunmadan yani amir kontrol ve onayı olmadan denetçi inisiyatifiyle kapatılabiliyordu. Bu durum da kapatılmaması gereken bir bulgunun kapatılmasına veya kapatılsa bile gerekli açıklamalar ve dokümantasyon olmadan kapatılmasına neden olabilmekteydi. İlgili işlemi gerçekleştiren denetçinin birimden ayrılması durumunda ise zamanında bu işlemin neden yapıldığına ve kimlerin onayıyla gerçekleştirildiğine dair bir veri elde edilmemekteydi.

Öte yandan açık ve kapalı bulgular hakkında Denetim Komitesi ve talep eden diğer üst yönetime zamanında ve sağlıklı veri sağlanmasında zorluklar yaşanmasına neden olabilmekteydi. Öyle ki şirketin karar vericileri konumundaki yönetim kuruluna bile denetim sonuçları ve bulguların durumları hakkında ilgili şirket süreçlerine ve problemlerine dair bilgi akışı sağlamada sorunlar ortaya çıkabilme riski olabilmekteydi.

İlaveten denetçilerin denetim esnasında gösterdikleri performanslarının da yıl içinde gerçekleştirdikleri denetim/proje bazında değerlendirmesi yapılamamakta ve arşivlenememekteydi. Dolayısıyla da her denetçinin aynı standartlara göre tarafsız ve adil şekilde değerlendirilmesinin yapıldığına dair iç denetim yönetimi tarafından güvence verilmesi mümkün olmamaktaydı. Bu dudum da denetçiler arasında motivasyon kaybına ve sonucunda yönetime olan güven kaybına yol açabilmekte, çok yetenekli ve yetkin personel kaybı riskini göz önüne serebilmekteydi. 


\section{2. İç denetim yazılımının kullanılması durumunda}

Yazılım kullanılmaması durumunda çoğu iç denetim çalışmalarının ve raporlamalarının manuel olarak yapılması, kontrol ve onay mekanizmalarının etkin ve verimli çalışmaması, arşivleme özelliğinin bulunmaması, anlık ve gerekli raporlamalarının doğru ve sağlıklı olarak sağlanamaması gibi birçok husus dikkate alındığında iç denetimin kendi süreçlerinde yazılım kullanım gerekliliği iç denetim yönetimi tarafından fark edilmelidir.

$\mathrm{Bu}$ farkındalığın oluşmasından sonra iç denetim biriminin yazılım kullanımı ile ilgili olarak seçebileceği iki seçeneği bulunmaktadır; dışarıdan yazılımın satın alınması veya iç kaynaklarıyla kendi bir yazılım geliştirmesi. Bu iki seçeneği de devam eden bölümlerde yine yazılım kullanımını tecrübe etmiş iç denetçilerden edinilen bilgiler 1şı̆̆ında inceleyeceğiz.

\subsubsection{Satın alınan iç denetim yazılımının kullanılması durumunda}

Şirket dışından satın alınan yazılımın kullanıldığında yazılım kullanımını tecrübe etmiş denetçilerle yapılan görüşmeler neticesinde, iç denetim yazılımı dışarıdan satın alıp birimlerinde kullanmış iç denetim birimlerinde iç denetim safhalarına ve uygulamalarına dair daha detay bilgiye özet olarak aşağıda yer verilmektedir. Ayrıca yazılıma dair olumlu ve olumsuz bulunan özellikler de aşağıda sıralanmaya çalışılmıştır.

Mevcutta piyasa doğrudan denetim faaliyetlerine odaklı bir yazılım çok fazla olmamakla birlikte ERP sistemleri olarak satılan uygulamaların bir alt modülü olarak denetim modülleri satılmaktadır. Çalışmamızda konu ettiğimiz örnekte dışarıdan satın alınan ve GRC olarak nitelendirilebilecek bir uygulamanın alt modülü olarak çalışan bir iç denetim yazılımından bahsedilerek konu açıklanmaya çalışılmaktadır.

\subsubsection{Planlama}

GRC yazılımının devreye alınması sonrasında planlama aşamasındaki tüm aşamalar (yukarıda adım adım yazıldığından ayrıca burada belirtilmemiştir) her ne kadar dışarıdan manuel olarak yapılmaya başlansa da yine de tam olarak kullanıldı demek mümkün olmamaktaydı. Ancak yine de bu alanların bulunması yapılması gerekenler konusunda henüz çok tecrübesi olmayan iç denetim birimini iyi yönlendirmekteydi. Sonuç olarak ilgili adımlar/süreçler manuel olarak devam etmekte ancak bilinçlenme daha fazlaydı.

Öte yandan bu adımlara dair işlemler ve dokümantasyon artık denetçi bilgisayarında veya muhafazasında değil sistem üzerinden daha sağlıklı bir şekilde takip edilebilmekteydi. Buradaki ana sorun ise yine GRC girişlerinin fiiliyattan çok daha sonra yerine getirilmesi idi. Bu da eş zamanlı olarak işlemlerin kaydedilmemesi sonucu olası hatalı kayıt yapma durumunu demekti.

\subsubsection{Denetimin yürütülmesi}

Genel olarak denetimin yürütülmesi aşamasındaki adımların GRC'den sonra sadece denetçi inisiyatifinde yürüyen işlemler olmaktan çıkarılmıştı zira bunlara dair GRC üzerinden tamamlanması gereken alanlar vardı ve onayları alınmadan denetimin tamamlanmasına izin verilmemekteydi.

Denetimin yürütülmesi esnasındaki diğer adımlarla ilgili olarak genel itibariyle tüm süreç adımlarının manuel olarak yürütülmekle birlikte artık bunların dokümante edilmesi zorunluluğu başladığından en azından bu adımların izlenmesi gerektiği ve tamamlandığına dair dokümantasyon gerekliliği denetçiler tarafından öğrenilmişti. Bun farkındalığın oluşması, dokümantasyonun yapılmaya başlanması ise yapılan çalışmalarda ve dokümantasyonda yeknesaklığın yavaş yavaş sağlanmasına, arşivlemenin sadece denetçi bilgisayarlarında bulunmasından öte artık GRC üzerinde yapılmasına, denetim esnasında yapılan risk değerlendirmesi ve sonuçlarından başka çalışmalarda faydalanılabilecek hale gelmesine zemin hazırlamaktaydı.

Ayrıca belirtmekte fayda var ki denetim saha çalışmalarının daha düzenli dokümante edilebiliyor olması ve amir tarafından daha kolay kontrol edilebiliyor olması denetim raporuna giren bulgular dışında testi yapılıp yeterli görülen testlerinde kontrol edilebilme kolaylığını sağlamaktaydı. Tabi bu elbette GRC'yi kullanan ve denetçi ve yönetim kademesinin hassasiyetine bağlı olmaktaydı. 
Ancak eşzamanlı kullanım konusunda sıkıntılar bulunmaktaydı. Yazılımın eş zamanlı kullanılmamasıyla ilgili olarak kök nedenlere dair zamanında bu tip yazılımları kullanan denetçilerin verdiği ortak cevaplar ise; kullanıcı dostu bir ara yüzün olmaması, GRC yazılımı kullanımının çok karmaşık olması, kullanılmayan bir çok modül ve alan olması, olası problem ve arızalarda dışarıya bağımlı olunduğundan anında destek sağlanmasında sıkıntılar yaşanması olarak sıralanabilir.

\subsubsection{Raporlama}

$\mathrm{Bu}$ iç denetim süreci GRC yazılımı kullanımı durumunda da denetim yönetimi ve denetçiler tarafından en çok hassasiyet gösterilen denetim aşaması olmaya devam etmekteydi.

Bu süreç nihai denetim raporunun gerek denetim yönetimi tarafından gözden geçirilmesi ve onaylanması, gerekse sonrasında denetlenen birimlerle mutabakatı ve sonrasında şirket üst yönetimi ve sonrasında Denetim Komitesi ile paylaşılması adımlarını içerdiğinden oldukça önem arz etmekteydi. Arşivleme açısından hem mutabakat öncesi taslak rapor versiyonları, hem mutabakat sonrası versiyonlar ve nihai raporlar, Denetim Komitesi sunumlarında yer alan raporla ilgili kısımların arşivlemesine GRC olanak sağlamaktaydı.

\subsubsection{Denetim sonuçlarının izlenmesi}

Denetim raporlaması tamamlandıktan sonra bulgulara dair gerekli aksiyonların belirlenen vadelerde alınıp alınmadığı, alınmadığıysa gerekçeleri, olası yeni aksiyon planlarının alınması gibi işlemlerin takibinin merkezi ve konsolide olarak tek bir sistem üzerinden yapılabilmesine GRC olanak sağlamaktaydı.

Ancak GRC'nin kullanımının eşzamanlı olmaması yine de hangi denetimin hangi bulgusunun kapatıldı̆̆ına dair yönetime anlık bir raporlama yapılamamaktaydı. Bu sürecin yine dışarıdan maalesef takip edilmesi gerekmekteydi. Bu da karar vericilere destek olacak bir yönetim raporlama mekanizmasının tam istenildiği gibi çalışmasına engel olmaktaydı.

Denetim bulgularının GRC üzerinden takip edilip gerekli onaylar alınarak kapatılması veya vadelerinin gerekçeleri yazılarak revize edilmesi gereğine dair farkındalık ise bu tip yazılımların kullanılmasıyla oluşmuştu. Gerekli onay mekanizmaları bulunmadan yani amir kontrol ve onayı olmadan denetçi inisiyatifiyle bulgu kapatılması daha zor olmaktaydı.

Ancak kullanımdan ötürü manuel olarak eğer amir kontrol etmezse denetçiler herhangi bir dokümantasyon yapmadan bulguları kapatabilmekte veya vadelerini revize edebilmekteydi. Bu durum da kapatılmaması gereken bir bulgunun kapatılmasına veya kapatılsa bile gerekli açılamalar ve dokümantasyon olmadan kapatılmasına neden olabilmekteydi. Manuel işlemlere göre artısı artık ilgili işlemi gerçekleştiren denetçinin birimden ayrılması durumunda zamanında bu işlemin neden yapıldığına ve kimlerin onayıyla gerçekleştirildiğine dair bir verinin tam yeterli olmasa da elde edilebilmesiydi.

Öte yandan açık ve kapalı bulgular hakkında Denetim Komitesi ve talep eden diğer üst yönetime zamanında ve sağlıklı veri sağlanmasında zorluklar yaşanmaktaydı zira eşzamanlı ve doğru olarak GRC yazılımının kullanılması söz konusu olmamaktaydı.

Dolayısıyla şirketin karar vericileri konumundaki yönetim kuruluna bile denetim sonuçları ve bulguların durumları hakkında ilgili şirket süreçlerine ve problemlerine dair bilgi akışı sağlamada sorunlar ortaya çıkabilme riski olabilmekteydi.

Diğer önemli bir husus olan denetçilerin denetim esnasında gösterdikleri performanslarının da yıl içinde gerçekleştirdikleri denetim/proje bazında değerlendirmesi yapılamaması problemiydi. Denetçi performanslarına dair arşivlemede standart bir uygulama maalesef sağlanamamaktaydı.

Bundan ötürü her denetçinin aynı standartlara göre tarafsız ve adil şekilde değerlendirilmesinin yapıldığına dair iç denetim yönetimi tarafından güvence verilmesi mümkün olmamaktaydı. Bu durum da denetçiler arasında motivasyon kaybına ve sonucunda yönetime olan güven kaybına yol açabilmekte, çok yetenekli ve yetkin personel kaybı riskini göz önüne serebilmekteydi.

\subsubsection{GRC maliyeti ve diğer hususlar}

Maliyet açısından değerlendirmek gerektiğinde ise GRC tipi yazılımlar genellikle yurtdışı bir firmadan satın alınmakta ve önemli tutarlarda yıllık bakım işlemleri için ödeme yapılması gerekmekteydi. Ayrıca bu tip yazılımlar kullanıcı bazında lisans bedeli ödemesi yapılması gereken bir ERP yazılımı özelliği taşımaktaydı. 
İlaveten, doğrudan iç denetim biriminin ihtiyaçlarına göre tasarlanan bir ürün olmadığından, sonradan yazılım üzerinde bazı uyarlamalarla ihtiyacı kullanmaya yönelik tasarlandığından ihtiyaçları tam olarak sağlamada denetçiler tarafından eleştirilmekteydi.

GRC yazılımı kullanımı durumunda bunu tecrübe etmiş denetçilerden elde edilen bilgileri ve uygulamayı kısaca özetlemek gerekirse yapılan işlemler ve izlenen adımlar artık tamamıyla manuel olarak yürütülmemekte, yapılan işlemlerin ve izlenmesi gereken adımların sağlanmasında GRC hem yönlendirici hem kolaylıklar sağlayıcı bir araç olarak kullanılabilmekteydi. Özellikle arşivleme konusunda önemli katkılar sağlamaktaydı şöyle ki; dokümantasyon ve arşivleme yalnızca fiziki arşivde yazılı kopya olarak veya denetçi bilgisayarlarında Word, Excel gibi ofis programlarında yapılmamakta, artık bu işlemlere dair dokümantasyonda GRC kullanılabilmekteydi. Yapılan çalışmaların gözden geçirme, kontrol ve onay işlemleri de yeni yazılımla daha kolay bir hale gelmekteydi ancak yine de GRC kullanımının tam sağlanamaması bu alanlarda istenilen sonuçları elde etmede yetersiz kalabilmekteydi. Raporlamalar olarak GRC bir takım araçlar sağlayabiliyor olsa da anlık yönetim raporlaması ve bilgi sağlamada yeterli olmamaktaydı.

Eşzamanlı kullanım konusunda sıkıntıların bulunması GRC kullanımı açısından en önemli problem olarak gösterilebilirdi. Zira denetçiler tam olarak GRC'yi kabullenememişti, yukarıdan gelen zorlama ile yapılmak zorundan olması GRC'nin etkinliğini engellemekteydi. Yazılımın eş zamanlı kullanılmamasıyla ilgili olarak yukarıdaki bölümlerde değinildiği üzere kök nedenler; kullanıcı dostu bir ara yüzün olmaması, GRC yazılımı kullanımının çok karmaşık olması, kullanılmayan bir çok modül ve alan olması, olası problem ve arızalarda dışarıya bağımlı olunduğundan anında destek sağlanmasında sıkıntılar yaşanması olarak sıralanabilir.

\subsubsection{Kurum içi geliştirilen iç denetim yazılımı kullanımı}

D GRC tipi yazılımların kullanımının iç denetim ihtiyaçlarını istenildiği düzeyde karşılayamaması,

> Sürüm güncellemeleri için ilave maliyetlerin olması,

> Periyodik bakım işlemleri için bütçe gerekmesi,

> Sürüm güncellemesi ve periyodik bakımların yapılmaması durumunda yurtdışı firmalar tarafından teknik destek sağlanmaması,

> Her şeyden önemlisi önceki bölümlerde yer verildiği üzere denetçilerin/kullanıcıların GRC tipi uygulamaları kullanmayı benimsememesi ve eş zamanlı olarak kullanmaması

gibi nedenlerden ötürü kurum içi geliştirilen ve daha çok benimsenmesi mümkün yeni bir yazılım kullanılması söz konusu olabilir.

Bu kapsamda özellikle yüksek maliyet olmaması ve dışa bağımlılığa son verilmesi için in-House bir yazılım olması, ayrıca tamamen iç denetim ihtiyaçlarına uygun tasarlanması için iç denetim birimi denetçilerinin de bulunduğu bir proje ekibi tarafından yeni bir uygulamanın tasarlanmasına, gerektiğinde daha tasarlama aşamasında değişikliklerin ve geliştirmelerin yapılmasına karar verilmesi uygun olabilir.

$\mathrm{Bu}$ durumu yani iç denetim birimlerinde şirket içi geliştirilen ve birimde kullanılan yazılımı tecrübe etmiş denetçilerden elde edinilen bilgiye göre; iç denetimin fiilen uygulanan aşamalarına dair daha detay bilgiye özet olarak aşağıda yer verilmektedir. Ayrıca yazılıma dair olumlu ve olumsuz bulunan özellikler de aşağıda sıralanmaya çalışılmıştır. Bundan sonra da bu yazılım "yeni yazılım” olarak adlandırılmıştır.

\subsubsection{Planlama}

Denetim planlama aşamasının alt başlıkları olan adımlar artık manuel olarak yapılması elzem olan adımlar (Denetim Komitesinden yıllık denetim planı onayının alınması gibi) dışında tamamen bu yeni yazılım üzerinden yürütülmekte, bu işlemlere dair onaylar ve kontrollerin sağlıklı ve tam olarak yeni yazılım sayesinde gerçekleştirilmektedir. Bu durum arşivlemenin ve yönetim raporlamalarının da doğru ve tam olarak yapılabilmesine, anlık yönetim raporlamaları alınabilmesine 
de olanak sağlamaktaydı. Aynı GRC'de olduğu gibi bu yeni yazılımda da kullanıcıları yönlendiren adımların ve alanların bulunmasıyla ve iç denetimin tecrübesinin artık edilmiş olmasıyla denetim sürecine dair adımlar ve işler düzenli hale geçmiştir. Ancak risk değerlendirmelerinin sistem üzerinden yapılıp, etki olasılık hesaplamaları, şirketin süreçlerinin risk ve kontroller bakımından haritalandırılması gibi özellikler bakımından yeni uygulama henüz tam istenilen seviyede bulunmamaktadır. Bunda da yazılımın amacının tamamen denetim odaklı olup risk yönetimi süreçlerine ve risklerin önceliklendirilmesine dair ilk fazlarda bir geliştirme kararı alınmaması gösterilebilir.

\subsubsection{Denetimin yürütülmesi}

Yukarıdaki bölümlerde yer verilen denetimin yürütülmesi adımlarında tüm süreç adımlarının yeni uygulama üzerinden etkin olarak takip ve dokümante edilmesi zorunluluktan öte denetçiler tarafindan benimsenerek yerine getirilmektedir.

$\mathrm{Bu}$ durum artık denetim işlerinde farklı denetim ekiplerinde uygulamada yeknesaklı̆ğ ve işlerin daha standart yapılmasına olanak sağlamış ve işleri daha kolaylaştırmaktadır. Yine belirtmekte fayda olduğu üzere dokümantasyonun yapılmaya başlanması yapılan çalışmalarda ve dokümantasyonda yeknesaklığın yavaş yavaş sağlanmasına, arşivlemenin yeni sistem üzerinde yapılmasına, denetim esnasında yapılan risk değerlendirmesi ve sonuçlarından başka çalışmalarda faydalanılabilecek hale gelmesine yol açmaktadır.

Öte yandan denetim saha çalışmalarının düzenli dokümante ediliyor olması ve denetim yöneticileri tarafından işlerin daha kolay kontrol edilebilmesine ve denetim raporuna giren bulgular dışında testi yapılıp yeterli görülen testlerin de istenildiği zaman kolayca kontrol edilebilme kolaylığını sağlamaktadır.

GRC tipi yazılımlara nazaran yeni uygulamanın, iç denetçiler tarafından çalışmalarıyla eş zamanlı kullanılması daha etkin ve başarılı olmuştur. Bu başarıda her şeyden önce denetçilerin fikir ve görüşlerinin alınarak yen uygulamanın geliştirilmesi, yazılım geliştirme ekibinde (proje ekibinde) denetçilerin de yer alması ve onların görüşlerine göre geliştirmelerin yapılması, iç denetçilerin bu yazılımı benimsemesi önem arz etmektedir.

Ayrıca yeni uygulamanın kullanıcı dostu bir ara yüzün kullanılması, kullanımının çok basit kafa karıştırmayan bir şekilde olması, sadece bir tek modül -denetim- modülü bulunması, olası problem ve arızaların tamamen şirket iç kaynaklarıyla çözülebiliyor olması ve dışa bağımlılı̆̆ıın bulunmaması GRC kullanımında gösterilen direnci kırmıştır.

\subsubsection{Raporlama}

Bu kısım, nihai raporun gerek denetim yönetimi tarafından gözden geçirilmesi ve onaylanması, gerekse sonrasında denetlenen birimlerle mutabakatı ve sonrasında şirket üst yönetimi ve sonrasında Denetim Komitesi ile paylaşılması adımlarını içermektedir. Arşivleme açısından hem mutabakat öncesi taslak rapor versiyonları, hem mutabakat sonrası versiyonlar ve nihai raporlar, Denetim Komitesi sunumlarında yer alan raporla ilgili kısımların arşivlemesine GRC olduğu gibi yeni uygulama da olanak sağlamaktaydı.

\subsubsection{Denetim Sonuçlarının İzlenmesi}

Denetim raporlaması tamamlandıktan sonra bulgulara dair gerekli aksiyonların belirlenen vadelerde alınıp alınmadığı, alınmadığıysa gerekçeleri, olası yeni aksiyon planlarının alınması gibi işlemlerin takibinin merkezi ve konsolide olarak tek bir sistem üzerinden yapılabilmesine yeni uygulama da olanak sağlamaktaydı.

Ancak GRC'ye nazaran yeni uygulamanın kullanımı eşzamanlı olduğundan hangi denetimin hangi bulgusunun kapatıldığına dair yönetime anlık bir raporlama yapılabilmektedir. Bu da karar vericilere destek olacak bir yönetim raporlama mekanizmasının istenildiği gibi çalışmasını kolaylaş̧ırmaktadır.

Denetim bulgularının yeni uygulama üzerinden takip edilip gerekli onaylar alınarak kapatılması veya vadelerinin gerekçeleri yazılarak revize edilmesi gereği tüm denetçiler tarafından bilinir hale gelmiştir. GRC'ye göre farklılık olarak yeni uygulamada kapatılan bulguların risk seviyelerine göre ilgili amirin e-posta adresine bulgunun kapatılma veya güncelleme durum bilgisi manuel müdahaleye kapalı olarak otomatik olarak gönderilmektedir. Artık gerekli onay mekanizmaları bulunmadan yani amir kontrol ve onayı olmadan denetçi inisiyatifiyle bulgu kapatılması mümkün olmamaktadır. 
$\mathrm{Bu}$ durum da kapatılmaması gereken bir bulgunun kapatılmasını engellemekte, gerekli açıklamalar ve dokümantasyon olmadan kapatılmasına dair amir tarafından kontrollerin daha etkin yapılmasına imkân sağlamaktadır. GRC'de de olduğu gibi manuel işlemlere göre artısı artık ilgili işlemi gerçekleştiren denetçinin birimden ayrılması durumunda zamanında bu işlemin neden yapıldığına ve kimlerin onayıyla gerçekleştirildiğine dair bir veri yeterli olarak elde edilebilmektedir.

Öte yandan açık ve kapalı bulgular hakkında Denetim Komitesi ve talep eden diğer üst yönetime zamanında ve sağlıklı veri sağlanması daha kolaylaşmıştı zira eşzamanlı ve doğru olarak yeni uygulama kullanımı neredeyse sağlanmıştı.

Dolayısıyla şirketin karar vericileri konumundaki yönetim kuruluna denetim sonuçları ve bulguların durumları hakkında ilgili şirket süreçlerine ve problemlerine dair daha doğru ve tam aynı zamanında bilgi akışı sağlanabilecek duruma gelinmişti.

Diğer önemli bir husus olan denetçilerin denetim esnasında gösterdikleri performanslarının da yıl içinde gerçekleştirdikleri denetim/proje bazında değerlendirmesidir. Şöyle ki yeni uygulamanın denetim raporlama adımlarında yer aldığı üzere her denetim işinden sonra denetim ekibi üyelerinin performans değerlendirilmelerinin yapılması ve sisteme girilmesi gerekmektedir. $\mathrm{Bu}$ işlemler yapılmadan denetim tamamlanmasına sistem izin vermemektedir. Bu durum da kendi içinde bir kontrol sağlamıştır. Ayrıca bu kullanım denetçi performanslarına dair arşivlemede standart bir uygulama getirmiştir.

Böylelikle mükemmel olmasa da her denetçinin aynı standartlara göre tarafsız ve adil şekilde değerlendirilmesinin yapıldığına dair iç denetim yönetimi tarafından güvence verilmesinde aşama kaydedilmiştir. Bu durum da denetçiler arasında motivasyon kaybına azaltmakta ve sonucunda yönetime olan güveni artırmaktadır.

\subsubsection{5. Şirket içi geliştirilen iç denetim yazılımı maliyeti ve diğer hususlar}

Maliyet açısından değerlendirmek gerektiğinde ise yeni uygulama yazılımı in-House geliştirilen bir uygulama olduğundan satın alma bedeli, lisans bedeli veya periyodik bakım bedeli gibi dışarıya ödenen maliyet kalemlerini barındırmamaktadır. Yeni uygulama için katlanılan maliyet ise yazılım geliştirme aşamasından projede çalışan personelin projeye ayırdıkları zaman karşılık gelen saatlik ücretleridir.

Sürüm güncellemesi olması durumunda da yine bu işlemler şirket personeli tarafından yapılacağından ayrı bir maliyet oluşturmayacaktır. Ayrıca doğrudan iç denetim biriminin ihtiyaçlarına göre tasarlanan bir ürün olduğundan, ihtiyaçları tam olarak sağlamada denetçiler tarafından benimsenmişti.

Erişim ve gizlilik açısından incelendiğinde ise yeni uygulama yazılımı sadece denetçilerin kullanımına açık olan, diğer departmanların erişimine kapalı bir yazılımdır. Tüm yapılan işlemler log kayıtlarında tutulmakta, işlemler tarihçeye göre sıralanmakta ve bilgi istenildiği zaman yeni uygulamadan çekilebilmektedir. Ayrıca yetkilendirme işlemi ile tüm çalışanlara farklı yetkilerin tanımlanması şeklinde yapılabilmektedir. Şöyle ki denetim ekip üyesi, ekip şefi, başkan yardımcısı gibi rollere sahip kullanıcıların hepsinin farklı yetkileri olabilmekte ve bu yetkilere göre sistem üzerinde işlem yapabilmektedirler. Denetim çalışmalarında edinilmiş belge ve bilginin güvenli (şifrelenmiş) şekilde saklanması sağlanmaktadır.

Yeni yazılımın kullanımı durumunda uygulamayı kısaca özetlemek gerekirse yapılan işlemler ve izlenen adımlar artık neredeyse tamamıyla yazılım üzerinde yürütülmekte, yapılan işlemlerin ve izlenmesi gereken adımların sağlanmasında yeni uygulama hem yönlendirici hem kolaylıklar sağlayıcı bir araç olarak kullanılmaktadır. Özellikle arşivleme konusunda önemli katkılar sağlamasının yanında kontrol, onaylar, yönetim raporlamaları sağlamada da çok kolaylıklar getiren bir yazılım olmaktadır.

Yeni uygulamanın faydaları hakkında kullanıcılardan alınan dönüşlerin ortak özeti ise aşağıdaki hususları içermektedir:

> Yapılan yönlendirmeler ile denetimin hızını ve kalitesini artırmaya yardımcı olmaktadır.

> Denetimlerin standart şekilde yapılmasına kolaylık sağlamaktadır.

Kullanıcı dostu olup, kullanımı son derece basit ve kolaydır, GRC tipi yazılımlara nazaran karmaşık ekranları yoktur.

Kullanıcıyı yönlendirerek nerede ne yapması gerektiği hususunda yardımcı olmaktadır. 
Farklı görevlere sahip personel için farklı yetkilendirmeler /roller tanımlanabilmektedir.

Denetim çalışmalarında elde edilen bilgiler güvenli olarak kaydedilmektedir.

> Denetimde çalışmalarının daha kolay şekilde planlanmasına ve görev/iş yükü dağılımı yapılmasına yardımcı olmaktadir.

Denetim safhasındaki her işlemin yeteri seviyede kontrolden/onaydan geçmesi için onay mekanizması bulunmaktadır.

Denetçilerin denetimde hangi aşamada olduklarını takip etmelerini sağlamaktadır.

Gelişmiş arama imkânı sayesinde aranılan bilgi kolay ve hızlıca bulunmaktadır.

Dosya yönetim özelliği ile aranılan her türlü dosyaya kolaylıkla ulaşılmaktadır.

Çalışma kâğıtlarının ve dosyaların referanslanmasını sağlamaktadır.

Denetim çalışmalarını arşivlemektedir.

Kaliteli ve isteğe bağlı raporlama yapabilmekte ve etkin bir YBS aracı olarak kullanılabilmektedir.

\section{TARTIŞMA}

Teraman ve Şençiçek (Teraman \& Şençiçek, 2014) program kullanmakla ilgili olarak kullanıcıların yükünü azalttığını belirtmekte ancak programları kullananların da bu programları kullanmaya yetkin olması gerektiğine vurgu yapmaktadır. Bunu denetimle bağlayarak denetim yazılımlılarını kullanan denetçilerin yetkin olmaması geçerli bir denetimin yapılmasını da engellemektedir sonucuna ulaşmaktadırlar. Ayrıca bilgisayarlı denetim programları kullanmanın denetim çalışmalarını daha kolay ve hızlı yapılmasına destek veren bir araç olarak tanımlamışlardır.

Bu açıklamayı yeni iç denetim yazılımı özelinde yorumladığımızda, her ne kadar birçok denetim aşamasında iç denetim ve denetçilerin ihtiyaçları karşılayabilecek şekilde tasarlanmış ve denetçiler tarafından kabul görmüşse de hala ilerlemeye ve gelişime açık alanları bulunmaktadır. Şöyle ki; yeni uygulamayı kullanmak bu yazılımın her şeyi yapabileceği anlamına gelmemektedir. Zira yeni uygulama yazılımını kullanacak denetçilerin de yeteri kadar yazılım kullanma bilgisine ilaveten denetim fonksiyonunu yerine getirecek yetkinlikte olması gerekmektedir.

Teknik açıdan değerlendirildiğinde ise risk değerlendirme ve önceliklendirme çalışmalarına dair ilerlemeler yapılabilir. Aşağıdaki hususlarda geliştirmelerin yapılması denetim faaliyetleri ile riskin daha entegre çalışılmasını kolaylaştıracaktır:

Uygulamaya Şirket risk haritasının girilebilmesi (standart risk şablonları ve manuel eklemeler)

Uygulamaya Şirket kontrollerinin girilebilmesi (manuel ekleme)

Süreç - Organizasyon - Risk -Kontrol eşleştirmesinin yapılabilmesi

Risk değerlendirme (hesaplama) yapılabilmesi - (olasılık x etki = risk)

Risk değerlendirme sonuçları için süreç/organizasyon/risk seviyesi bazında yönetim raporlamalarının oluşturulabilmesi, istenilen seviyede raporların alınabilmesi.

\section{SONUÇ}

Günümüz dünyasında küreselleşmenin ve teknolojik gelişmelerin unsurları ve sonuçları dikkate alındığı denetime konu her alanda bilgisayar yazılımları ile iç içe yaşayan iç denetimin kendi iç süreçlerinde teknolojik gelişmelerden had safhada yararlanabileceği bir yazılımın kullanılmaması düşünülemez. Dolayısıyla gelecekte de iç denetim süreçlerinin tamamının yazılımlar kullanılmaksızın yürütülmesi söz konusu olmayacaktır kanaatini taşımaktayız. Bu çalışmada, işletmelerde iç denetim süreçlerinde bir iç denetim yazılımı kullanımının sağladığg faydalar incelenmiştir. İç denetim yazılımının kullanımı işletmeye risk haritası oluşturma, işletme kontrollerinin yapılabilmesi, süreç-organizasyon-risk ve kontrol eşleştirmelerinin 
yapılabilmesi, risk değerlendirmelerinin ve sonuçlarının yönetime sunulması için raporlanabilmesi gibi pek çok faydası bulunmaktadir.

Ayrıca, maliyetler açısından değerlendirildiğinde iç denetim yazılımının dışarıdan satın alma yoluyla temin edilmesi durumunda satın alma bedeli, lisans bedeli ve yıllık güncelleme ve bakım bedelleri bulunurken şirketin öz kaynakları ile in-House geliştirilen yazılım için satın alma bedeli, lisans bedeli veya periyodik bakım bedeli gibi ilave maliyet kalemleri bulunmadığından katlanılan maliyet oldukça az olacaktır.

Konunun daha önce ülkemizde bu detayda incelenmediği, yapılan çalışma ile iç denetim yazılımı kullanmanın iç denetim faaliyetlerine sağladığı etkilerin neler olduğunun gözler önüne serilmesi anlamında literatüre katkı sağlayacağı düşünülmektedir.

Hakem Değerlendirmesi: Dıș bağımsız.

Çıkar Çatışması: Yazarlar çıkar çatışması bildirmemiştir.

Yazar Katkıları: Çalışma Konsepti/Tasarım-G.A.; Veri Toplama-G.A.; Veri Analizi/Yorumlama-A.D.; Yazı Taslağı-A.D.; İçeriğin Eleştirel İncelemesi-A.D.; Son Onay ve Sorumluluk- A.D., G.A.

Finansal Destek: Yazarlar bu çalışma için finansal destek almadığını beyan etmiştir.

Peer-review: Externally peer-reviewed.

Conflict of Interest: The authors have no conflict of interest to declare.

Author Contributions: Conception/Design of Study-G.A.; Data Acquisition-G.A.; Data Analysis/Interpretation-A.D.; Drafting Manuscript-A.D.; Critical Revision of Manuscript-A.D.; Final Approval and Accountability- A.D., G.A.

Grant Support: The authors declared that this study has received no financial support.

\section{Kaynaklar/References}

Adiloğlu, B. (2010). İç denetim süreci ve temel işletme faaliyetlerinin kontrol prosedürleriyle değerlendirilmesi: Bir uygulama (Doktora Tezi). İstanbul Üniversitesi Sosyal Bilimler Enstitüsü, İstanbul.

Akolaş, D. A. (2004). Bilişim sistemleri ve bilişim teknolojisinin küreselleşme olgusu ve girişimcilik üzerine yansımaları. Selçuk Üniversitesi Sosyal Bilimler Enstitüsü Dergisi, 12, 29-43.

Babagil, M. T. (2021, Nisan 25). Yazılım-uygulama yazılımı, Alıntı adresi http://brahms.emu.edu.tr/babagil/bilg101Chapter5.pdf

Bilgen, İ. H. (2019). Yönetim bilgi sistemi tasarımında stratejik plana dayalı bilgi katmanları modeli. Bilişim Teknolojileri Dergisi, 12(1), 9-22.

Branding Türkiye (2021, Nisan 25). Yazılım nedir niye önemlidir yazılım çeşitleri nelerdir, Alıntı adresi https://www.brandingturkiye.com/ yazilim-nedir-niye-onemlidir-yazilim-cesitleri-nelerdir

Ceyhan, İ. F. (2010). İç denetim ve kurumsallaşma (Yüksek Lisans Tezi). Kırıkkale Üniversitesi Sosyal Bilimler Enstitüsü, Kırıkkale.

Çelik, A., ve Akgemci, T. (2010). Yönetim Bilişim Sistemleri, Gazi Kitapevi, Bölüm 1:13.

Damar, M., ve Coşkun, E. (2017). Üniversitelerde bilgi işlemden yönetim bilişim sistemlerine geçiş: Mevcut durum ve beklentiler. Bilişim Teknolojileri Dergisi, 10(1), 21-31.

Damar, M., Özdağoğlu, G., ve Özdağoğlu, A. (2019). Yazılımda kalite ve yazılım standartları: Bilimetrik bir araştırma. Organizasyon ve Yönetim Bilimleri Dergisi, 11(1), 51-66.

Durdu, A, İpek, E . (2020). Bilgi Yönetiminin İşletmelere Yenilik ve Rekabet Üstünlüğü Sağlaması. AJIT-e: Bilişim Teknolojileri Online Dergisi, 11(43), $105-114$.

Elibol, H. (2005). Bilişim Teknolojilerikullaniminin İşletmelerin Organizasyon Yapıları Üzerindeki Etkileri. Selçuk Üniversitesi Sosyal Bilimler Enstitüsü Dergisi, (13), 155-162.

Ekşi, B. (2021, Nisan 25). İç denetim süreci nedir? / iç tetkik prosesi aşamaları nelerdir?. Alıntı adresi https://www.burakeksi.com/ ic-denetim-sureci-nedir-ic-tetkik-prosesi-asamalari-nelerdir

Emhan, A. (2007). Karar verme süreci ve bu süreçte bilişim sistemlerinin kullanılması. Elektronik Sosyal Bilimler Dergisi, 6(21), 212-224.

Gencer, M. (2014). Bă̆ımsız denetimde iç kontrolün yeri ve önemi (Yüksek Lisans Tezi). İstanbul Gelişim Üniversitesi Sosyal Bilimler Enstitüsü, İstanbul.

Gökçen, B. A., ve Yelken, R. (2019). Holdinglerde risk odaklı iç denetim yapısı ve bir araştırma. Ida Academia Muhasebe ve Maliye Dergisi, 2(2), 155-177.

Günşen, M. H. (2016). Örnek bir iç denetim uygulaması: Tedavi sürecinin faturalandırılması süreci. Denetişim Dergisi, (9), 74-86.

Gökçen, H. (2011). Yönetim Bilgi/Bilişim Sistemleri: Analiz ve Tasarım, 2.Baskı, Ankara:11-65.

İç Denetim Portali (2021, Nisan 25). Alıntı adresi http://www.icdenetim.net

Kaya, B. (2021, Şubat 01). İç denetim, iç kontrol ve risk yönetiminde kullanılan yazılımlar. Alıntı adresi http://bertankaya.net/2013/09/ ic-denetim-ic-kontrol-ve-risk-yonetiminde-kullanilan-yazilimlar

Kurnaz, N., ve Çetinoğlu, T. (2019). İç denetim-güncel yaklaşımlar. Kocaeli: Umuttepe Yayınları.

Sağlar, J., ve Tuan, K. (2009). İşletmelerde iç denetim fonksiyonunun bağımsız dış denetim maliyeti üzerindeki etkileri. Çukurova Üniversitesi Sosyal Bilimler Enstitüsü Dergisi, 18(1), 343-358. 
Şahin, Ș. (2014). Bilişim Sistemleri Uygulamalarının İşletme Performansına Etkileri. Dicle Üniversitesi İktisadi ve İdari Bilimler Fakültesi Dergisi, 2(6):43-56.

Türk Dil Kurumu Sözlükleri (2021, Nisan 25). Alıntı adresi https://sozluk.gov.tr.

Türkiye İç Denetim Enstitüsü (TIDE) (2021, Nisan 25). İç denetimin paydaşlar için değeri. Alıntı adresi https://www.tide.org.tr/file/documents/pdf/ IIA_Ic_Denetimin_Paydaslar_Icin_Degeri_Detay.pdf.

Türkiye İç Denetim Enstitüsü (TIDDE) (2021, Nisan 25). İç denetimin tanımı. Alıntı adresi https://tide.org.tr/page/26/Ic-Denetimin-Tanimi Yazılımnet Bilişim Teknolojileri (2021, Nisan 25). Yazılım nedir. Alıntı adresi http://www.yazilimnet.com/tr/blog/20/yazilim-nedir 
